\title{
LEGAL PROTECTION TO PEDESTRIANS IN SAMARINDA
}

\author{
Suwardi Sagama \\ Sharia Faculty of IAIN Samarinda \\ Jl. H. A. M. Rifaddin, Harapan Baru, Kec. Loa Janan Ilir, Kota Samarinda, Kalimantan Timur 75251 \\ e-mail: suwardisagama.recht@gmail.com
}

\begin{abstract}
Abstrak: Pertumbuhan penduduk di Kota Samarinda pada tahun 2017 dan 2018 berdampak pada meningkatnya pembangunan dan pertumbuhan kendaraan bermotor yang signifikan. Pertumbuhan kendaraan tidak didukung dengan ketersediaan lahan parkir, sehingga trotoar menjadi tempar parkir kendaraan bermotor. Bagaimana perlindungan hukum kepada pejalan kaki pada ruang publik di Kota Samarinda dan faktor penghambat dan pendukungnya. Metode penelitian yang digunakan yuridis empiris dengan menerapakan peraturan perundang-undangan sebagai landasan argumentasi hukum. Serta melakukan wawancara kepada instansi terkait yang berhubungan dengan penelitian. Pejalan kaki pada ruang publik di Kota Samarinda dilindungi oleh hukum dalam Pasal 25 ayat (1) Undangundang Nomor 22 Tahun 2009 tentang LLAJ. Setiap jalan yang digunakan untuk lalu lintas umum wajib dilengkapi trotoar untuk Pejalan Kaki. Trotoar di Kota Samarinda menjadi tempat berjualan pedagang kaki lima dan parkir kendaraan bermotor. Faktor penghambat yaitu ketersediaan anggaran yang terbatas, trotoar digunakan berdagang oleh pedagang kaki lima, trotoar menjadi tempat parkir kendaraan bermotor. Faktor pendukung yaitu adanya kepastian hukum, terwujudnya ketertiban hukum dan perlindungan hukum kepada siswa/i.
\end{abstract}

Kata Kunci: Trotoar; Pejalan Kaki; Perlindungan Hukum

\begin{abstract}
Population growth in Samarinda in 2017 and 2018 had an impact on the increasing development and significant growth of vehicles. Vehicle growth was not supported by the availability of parking lots, so the sidewalks became parking lots for vehicles. This research intended to find the legal protection for pedestrians in public spaces in Samarinda and its obstacles and supporting factors. The research method used was an empirical and juridical legal study by applying the laws and regulations as the basis for legal argumentation, as well as conducting interviews with relevant agencies related to research. Pedestrians in public spaces in Samarinda were protected by legal norms in Article 25 paragraph (1) of Law Number 22 of 2009 concerning Traffic and Road Transportation. Every road used for public traffic must have sidewalks for pedestrians. Sidewalks
\end{abstract}


in Samarinda had become a place for hawkers to sell and for riders or drivers to park their vehicles. The inhibiting factors were the limited availability of the budget, sidewalks for trading by hawkers, sidewalks for parking lots. Supporting factors were legal certainty, the realization of law order, and legal protection for students.

Keywords: Sidewalks; Pedestrians; Legal Protection

\section{INTRODUCTION}

Samarinda is the capital of East Kalimantan. As a capital city, an increasing population is a consequence that must be accepted. Besides as a symbol of the Province, a capital city is also a place to be visited by people from outside, even for looking for a job or living because it is potential and productive for the future. Therefore, the population is inevitable. Civil Registry Office of Samarinda recorded significant population growth in Samarinda for the last two years from 2017 to 2018. In 2017 there were 769,632 people, and in 2018 there were 778,883 people $^{1}$.

The increasing number of population in Samarinda was in line with the development of this city. The forest had turned into potential and economical buildings, such as residential areas, stores, malls, banks, and hotels. The existence of

1 "Population in Samarinda from 2017 to 2018" (Civil Registry Office of Samarinda, 2018).

${ }^{2}$ Agung Dwiyanto, "Kuantitas Dan Kualitas Ruang Terbuka Hijau Di Pemukiman new buildings influenced some changes in society to adjust its dynamic developments. The development had an impact on decreased open space so that there was a risk in the decrease of the society's psychology ${ }^{2}$. The government could see in balance the development based on rights and obligations. On one side the development could increase the rate of population growth, but on the other hand, the potential for conflict or problems could occur at any time.

The conflict or problems can be caused by no availability of supporting infrastructure. So, it is an obligation to provide the supporting infrastructure of the new buildings such as parking lots, pedestrian areas, and others to ensure balance in the society. An infrastructure acts as a facility which built and needed for the work of the social and the economic system in the society ${ }^{3}$. The government

Perkotaan,” Jurnal Teknik 30, no. 2 (2009): 8893.

${ }^{3}$ Warsilan Warsilan and Akhmad Noor,

"Peranan Infrastruktur terhadap Pertumbuhan Ekonomi dan Implikasi pada Kebijakan 
can see this problem comprehensively because by the time goes by, the needs will be increased.

If there is a lackness of parking space for vehicles, a sidewalk will be a parking lot. The space on the road space used for parking can endanger pedestrians and pedestrian circulation ${ }^{4}$. Some roads have become parking lots and it is legalized. Moreover, there are sidewalks used by hawkers as places to sell. As a result, pedestrians lose their rights. Pedestrians also have the potential to become victims of traffic accidents. The riders who use the sidewalk to avoid traffic jams can graze children who walk on the sidewalk ${ }^{5}$.

This condition clearly disadvantage other parties who use the sidewalk to walk. The regulation to protect pedestrian rights was stipulated in Law Number 22 of 2009 concerning Traffic and Road Transportation. Article 25 paragraph (1) letter h said that every road used for public traffic must be equipped with road equipment. One of them is in the form of a supporting facility

Pembangunan di Kota Samarinda," MIMBAR: Jurnal Sosial Dan Pembangunan 31, no. 2 (2015): 359-366.

${ }^{4}$ Rachmat Prijadi and Raymond D. Ch Tarore, "Pengaruh Permukaan Jalur Pedestrian Terhadap Kepuasan \& Kenyamanan Pejalan Kaki Di Pusat Kota Manado," Media Matrasain 11, no. 1 (2014): 43-54. such as a sidewalk. However, the government's obligation to provide sidewalks is not in line between das sein and das solen.

Based on that background, the researcher drew two research problems: 1) How is the legal protection of pedestrians in public spaces in Samarinda? 2) What are the supporting factors and obstacles in implementing law number 22 of 2009 concerning Traffic and Road Transportation to the pedestrians in public spaces in Samarinda?

The purpose of the study was to determine the legal protection to pedestrians in public spaces in Samarinda and to find out the supporting and inhibiting factors in the implementation of Law Number 22 of 2009 concerning Traffic and Road Transportation to the pedestrians in Samarinda.

\section{METHOD}

The type of this research was an empirical and juridical legal study. This research focused on regulations related to roads and pedestrians, which supported

\footnotetext{
5 "Kasus Pengendara Sepeda Motor Serang Pejalan Kaki Berakhir Damai," Tribunnews.com, September 10, 2019, https://www.tribunnews.com/metropolitan/2019 /09/10/kasus-pengendara-sepeda-motor-serangpejalan-kaki-berakhir-damai.
} 
from empirical results or law practices aimed at law enforcement. This was descriptive research. Researchers described in detail the problems that occur such as about rights owned by pedestrians, authorization to carry out law enforcement when violations that harm pedestrians occurred. The data were obtained through interviews, observations, and documentation to relevant agencies namely The Public Works, Spatial Planning and Public Housing Office, Department of Transportation, Trade Office, and municipal police of Samarinda. To get a good research result by using the method of direct observation on the road crossed by motorized vehicles, conducting interviews, and studying documents.

\section{FINDING AND DISCUSSION}

\section{Legal Protection to Pedestrians in Public Spaces in Samarinda}

The Republic of Indonesia is a country of law. The legal consequences must be carried out by the regulators, social societies, and law enforcers professionally and fairly. The legal mandate is in Article 1 paragraph 3 of 1945 Constitution of the Republic of Indonesia, that the State of Indonesia is the State of Law. Philipus M. Hadjon in
Ni'matul Huda said that the concept of the state of law was on two major legal systems namely civil law with administrative characteristics and common law with judicial characteristics ${ }^{6}$.

The application of a legal characteristic is to enforce the law without seeing any difference in economic status, social strata, and position, because everyone is equal for the law (read: Court). In the state of law, the authority must not be only for a particular person or institution, because it can lead to authoritarianism and arbitrariness. So, the authority must be separated for the realization of checks and balances as the trias political concept conceived by Montesquie, namely legislative, executive, and judiciary. Indonesian had interpreted the ideas brought by Montesquie into the practice of state administration by dividing the authority into three institutions namely the legislative, executive, and judiciary.

There is no intervention and distortion in the highest state institution which separated in Indonesia because everything works according to its different authority. In the constitutional system in Indonesia, the executive agency has a

${ }^{6}$ Ni'matul Huda, Ilmu Negara (Jakarta:

Rajawali Press, 2010), 93. 
62 | Suwardi Sagama, Legal Protections to Pedestrians..., hlm.56-70

significant role for government and state affairs, because it interacts directly with society and other countries through international organizations and cooperations. The executive or government administration does not only depend on the central government but the provincial or regional government.

The regional government, including the regional government of Samarinda, is a part of the Republic of Indonesia, which must organize government affairs following its authority. Duties and responsibilities of the regional government were firmly regulated in the law on regional government in Article 11 paragraph (1) of Law Number 23 of 2014 concerning Regional Government. It is stated that the authority of the regional government is a concurrent government affair, meaning that the government divided into the central government and the provincial and local governments. Consequently, the provincial and local governments must not be apathetic with their obligations.

Article 12 has been stated that in concurrent affairs there are basic services including those in letter 'e' which states

\footnotetext{
${ }^{7}$ Hans Kelsen, General Theory of Law and State, trans. Anders Wedberg (New Jersey: The Lawbook Exchange, Ltd., 2007), 100.
}

that the regional government is obligatory to fulfill peace, public order, and community protection. The word 'obligatory according to the Great Dictionary of the Indonesian Language of the Language Center (in Indonesian means $\mathrm{KBBI}$ ) means the must to implement, and should not be ignored. So, it is obligatory in the provision of Article 12 of the Law on Regional Government that is a necessity organized by the government. This obligation also applies to the regional government of Samarinda, which was stated in Article 131 Paragraph (1) of Law Number 22 of 2009 concerning Traffic and Road Transportation, that pedestrians were entitled to the availability of supporting facilities such as sidewalks, crossings, and other facilities.

The availability of these facilities is a pedestrian's right that can guarantee public order and provide good protection to the people of Samarinda. If that right is a legal right, the right must be a right for the others' actions, or an activity appropriate to the law is a legal obligation of another person ${ }^{7}$. So, a right in society is a government's obligation to be fulfilled and implemented. Rights are absolute, cannot be reduced or eliminated. Every 
right must also have an obligation because it can not be separated to regulate the pedestrians' rights and obligations in maintaining the availability of the facilities.

The right is a challenge for the government, whether the obligation to protect the society can be done or not. The sidewalks are not only to fulfill the order of the law but also to provide safety for pedestrians to do their daily activities at certain times on foot. The commercial users and vehicles on the sidewalk can endanger pedestrians ${ }^{8}$. Supporting facilities for pedestrians are built on the road. As it is known, the road is not only used by pedestrians but also vehicles. The definition of road based on Law No. 38 of 2004 concerning Roads is a land transportation infrastructure covering all parts of the road such as complementary buildings and equipment for traffic on, above, and below the surface of the land and/or water surface except railroad tracks, lorries tracks, and cable roads?.

Based on the explanation above, it has been confirmed that the existence of

\footnotetext{
${ }^{8}$ Chaerul Muchtar, "Identifikasi Tingkat Kenyamanan Pejalan Kaki : Studi Kasus Jalan Kedoya Raya - Arjuna Selatan," Jurnal Planesa 1, no. 2 (2010): 153-159. 9 "Law of The Republic of Indonesia Number 34 of 2004 Regarding Road," 2004.
}

roads is very comprehensive. The road is not just a medium for vehicles but is also used by pedestrians for their physical and mental health, so it must be equipped with supporting facilities. The sidewalks should be pleasant because they affect a healthy walking culture and reduce pollution because of vehicles' emissions ${ }^{10}$. So, it is reasonable if the pedestrians should be protected by the government because the road becomes a public facility controlled by the government. However, supporting facilities such as sidewalks were not a priority for the government of Samarinda. Based on the results of an interview, Budi Santoso said that the Public Works and Spatial Planning Office (PU-PR) had never built sidewalks on any street in Samarinda. Samarinda was currently focusing on building roads for vehicles and repairing damaged roads.

The absence of sidewalks in Samarinda became a fact that the Government of Samarinda did not carry out the mandate of Law Number 22 of 2009 concerning Traffic and Road Transportation as referred to the state of law. The availability of facilities for

\footnotetext{
${ }^{10}$ Liliek Satriyadi, Bambang Haryadi, and Ismiyati -, "Prasarana Pedestrian di Lingkungan Kampus: Studi Kasus Kampus UNDIP dan UNNES," Wahana Teknik Sipil: Jurnal Pengembangan Teknik Sipil 22, no. 1 (2017): 58-70, https://doi.org/10.32497/wahanats.v22i1.902.
} 
64 | Suwardi Sagama, Legal Protections to Pedestrians..., hlm.56-70

pedestrians was not in line with the growth of construction in Samarinda. Building constructions in Samarinda was very fast. Based on observations made by the researcher in Samarinda, it was found that buildings in Samarinda, whether small, medium or large, did not have sufficient parking areas for visitors' vehicles.

Furthermore, buildings that did not have special facilities for pedestrians could directly impact the traffic of vehicles on the highway. The road had been used as a parking area for twowheeler and four-wheeler, as well as a place used by pedestrians. Likewise, on the sidewalk, there were parking prohibition signs, but people still used it as a parking area. This condition affected the sense of security and comfort in the use of sidewalks and the absence of plants.

Pedestrians did not feel comfortable due to the lack of trees that could protect them from the $\operatorname{sun}^{11}$.

Based on the interview with Vincentius Hari Prabowo ${ }^{12}$, Samarinda Transportation Office had punished the

${ }^{11}$ Siti Nurjanah Ahmad and Try Sugiyarto Soeparyanto, "Tinjauan Perilaku Pejalan Kaki Dan Penyeberang Jalan Pada Kawasan Fakultas Pertanian Universitas Haluoleo," Stabilita:

Jurnal Ilmiah Teknik Sipil 1, no. 3 (2013): 275290.

${ }^{12}$ Vicentius Hari Prabowo, Interview with V. Hari Prabowo on Punishment Activities traffic violators, especially for the owners of either two-wheeler or four-wheeler. The punishment of the misuse of parking areas on the sidewalk was done incidentally. This punishment was taken during daily patrols or from the reports, so there was no data on the number of sidewalk abuse written in the Transportation Office of Samarinda.

This fact was also expressed by Boy Leonardo Sianipar ${ }^{13}$. He said that the punishments for the hawkers selling on sidewalks were also done incidentally such as from reports or daily patrols by personnel of 190 people with each team of 10 people. Before the punishments were carried out, warnings were given first, if it was not obeyed, the confiscation will be done.

Based on the interview with the Transportation Department and municipal police of Samarinda showed the level of law awareness to give rights for pedestrians was still low. It was proved by the misuse of the sidewalks. Providing legal protection to pedestrians was one of the government's obligations. Pedestrians

Implemented by the Samarinda Transportation Office, July 2019.

${ }^{13}$ Boy Leonardo Sianipar, Interview with Boy Leonardo Sianipar on Punishment Activities Implemented by the Samarinda Transportation Office, July 2019. 
had the right to get proper facilities in public spaces on sidewalks.

Article 25 paragraph (1) letter 'g' of Law Number 22 of 2009 concerning Traffic and Transportation that every road used for public traffic must be equipped with road equipment such as supporting traffic facilities on the road and side of the road. In the letter ' $h$ ', it was explicitly stated that every road used by the public must provide facilities for pedestrians.

The presence of sidewalks near schools and traditional markets was highly useful for pedestrians. Public spaces in these areas were called external public service accessed by everyone ${ }^{14}$. Pedestrian activities in schools and traditional markets were very active. The sidewalks eased their dynamic activities. In rush hours, overcrowding was unavoidable. It was in the morning at 06.30-07.30 Wita, midday at 12.30-13.50, and in the afternoon at 16.15-17.55 Wita, even until night. The congestion occurred continuously during the rush hours, except for holidays or weekends. Besides,

\footnotetext{
${ }^{14}$ Yusuf Adam Hilman, "Revitalisasi Konsep Alun-Alun sebagai Ruang Publik: Studi Pemanfaatan Alun-Alun Ponorogo," Jurnal Aristo 3, no. 1 (2016): 28-37, https://doi.org/10.24269/ars.v3i1.9. 15 "Educational Data of 2018/2019, Second Semester: Private and Public Primary and Junior High Schools" (Department of Education and Culture of Samarinda, 2019).
}

the absence of sidewalks could endanger both pedestrians and riders during working / active school hours.

Based on data obtained from the Department of Education and Culture in Samarinda, there were 219 public and private schools for primary schools and 88 junior high schools ${ }^{15}$. While, the public and private high school schools were 105 schools $^{16}$, and the Islamic high schools were 12 schools $^{17}$. The total number of schools in Samarinda was 424 schools. If each school had an average of 30 students per class, the total number of students was 12,720 students.

Based on observations at schools that have sidewalks in Samarinda, the functions of the sidewalks were used by students to walk, by hawkers to sell, and by riders to park. This condition forced students to use two alternatives. First, they kept using the sidewalk even though they had to be on the edge of the narrow space of the sidewalk. Second, they chose to go down to the road used by vehicles. This condition had taken the rights of the

\footnotetext{
16 "Educational Data of 2018/2019, Second Semester: Private and Public Senior High Schools" (Department of Education and Culture of East Kalimantan, 2019).

17 "Educational Data of 2018/2019: Private and Public Islamic High Schools" (Regional Office of Ministry of Religious Affairs of East Kalimantan, 2019).
} 
pedestrians who were supposed to use the sidewalks. So, the government of Samarinda must provide spaces for pedestrians to avoid the right violation.

The same thing happened in traditional markets, pedestrians must take turns with riders in using the road. Based on data obtained from the Office of Market Service of Samarinda, there were twelve traditional markets in Samarinda ${ }^{18}$. Every morning and certain times, the conditions in the traditional market were the same as the other traditional markets, which were crowded with buyers. The results of observations showed that people who sold at traditional markets not only sold inside the markets but also outside. Legally, selling outside the markets had violated the provisions of the law. The government of Samarinda could give punishment to the hawkers who did not follow the rules as regulated in the provisions of the legislation.

Based on Presidential Decrees No. 112/2007 concerning the Arrangement and Development of Traditional Markets, Shopping Centers, and Modern Stores, the arrangement of traditional markets was to create order in

\footnotetext{
18 "Data of Markets in Samarinda" (Office of Market Service of Samarinda, 2018).

19 "Regulation of the President of the Republic of Indonesia on Administration and
}

the market area. Article 2 paragraph (2) letter ' $b$ ' stated that the traditional market should provide a parking area at least for a four-wheeler in $100 \mathrm{~m}^{2}$ (one hundred square meters). ${ }^{19}$ The legal provision as mentioned in the decree was very clear that traditional markets must provide parking lots and maintain order so that the visitors could feel safe when visiting traditional markets. Moreover, other people who used pedestrian facilities did not hesitate to use it.

Spaces for pedestrians should be properly used by pedestrians. Ministerial Decree Number 19 / PRT / M / 2011 stated that in bridges, upper cross streets, lower cross streets, flyovers, tunnels, and complementary buildings must provide a sidewalk with a width of at least 0.5 (zero point five) meters. Roads were not only owned by vehicles such as cars and motorcycles but were also owned by pedestrians. The sidewalk construction must be built. The government was required to provide facilities for pedestrians on the right and left side as stated in Ministerial Decree Number 19 / PRT / M / 2011 regarding Road

Development of Traditional Market Shopping Centres and Modern Store," 2007, https://www.bphn.go.id/data/documents/07pr11 2.pdf. 
Technical Requirements and Road Technical Planning Criteria.

Article 10 paragraph 2 stated that in the condition of limited space in the road, the width of the roadside could be used for the sidewalk. ${ }^{20}$ For this provision, the government of Samarinda was obliged to carry out its governmental duties to provide sidewalks. Based on Article 3 number 5 of Law Number 28 Year 1999 concerning the Administration of a Clean and Free of Corruption, Collusion, and Nepotism State, the government in implementing the general principles of State administration should be proportional. Consequently, the Government, including the government of Samarinda, had the duty to fulfill the principle of proportionality, which was the principle to prioritize the balance of rights and obligations of the state administrators. ${ }^{21}$

Constitutionally, there were obligations for the government, but their regulations did not give any sanction to the government. Law Number 22 of 2009 concerning Traffic and Road

20 "Regulation of Minister of Public Works Number 19/ PRT / M / 2011 on Road Technical Requirements and Road Technical Planning Criteria," 2011.

21 "Law of the Republic of Indonesia Number 28 of 1999 Regarding the Organization of a State That Is Clean and Free from Corruption, Collusion and Nepotism," 1999,
Transportation only regulated the sanctions for a person who damaged a pedestrian facility as mentioned in article 275 Paragraphs (1) and (2) ${ }^{22}$. In another article, Article 284 emphasized that a sanction for riders who used public traffic without prioritizing pedestrian safety ${ }^{23}$. A provision that regulated an obligation, but did not give any sanction was a legal uncertainty.

The Law Number 22 of 2009 concerning Traffic and Road Transportation should accommodate a sanction to those who did not carry out their obligations, in this case was the government. It was also contradicted to Law Number 28 of 1999 concerning the administration of a clean and free of corruption, collusion, and nepotism state. In article 3 number 1 , it was stated that the administrators of the government applied the principle of legal certainty, which was the principle in the state of law that prioritized the foundation of the laws and regulations, propriety and justice in every policy. As a state of law, the government could not ignore the legislation that had

https://www.kpk.go.id/gratifikasi/BP/uu_28_19 99.pdf.

22 "Law of the Republic of Indonesia Number 22 of 2009 Concerning Road Traffic and Transportation," 2009.

23 "Law of The Republic of Indonesia Number 22 of 2009 Concerning Road Traffic and Transportation," 2009. 
68 | Suwardi Sagama, Legal Protections to Pedestrians..., hlm.56-70

been legalized, unless it had been aborted or annulled by law.

Obstacles and Supporting Factors in the Implementation of Law Number 22 of 2009 on Traffic and Road Transportation to Pedestrians in Public Spaces in Samarinda

Regulations were requirements for the state of law. The existence of regulations was to give controlled actions to everyone. Each regulation consisted of rights and obligations to everyone in all economic status, education levels, positions, and ages as in the regulations Act Number 22 of 2009 and article 25 verse (1) letter 'h'. Providing sidewalks was an obligation for the government, while sidewalks were an absolute right for pedestrians. However, the government of Samarinda as the implementer of the regulation did not accomplish the orders from the law of traffic and road transportation. So, it was important to look at the obstacles and supporting factors of the implementation of Law Number 22 of 2009 concerning Traffic and Road Transportation.

\section{The Obstacles}

\section{The Limitation of the Budget}

The study found that the government of Samarinda did not construct sidewalks; it merely repaired Jalan Kusuma Bangsa and Jalan Pahlawan. Budi Santoso, the head of the Road and Bridge Maintenance Department of Public Works and Spatial Planning in Samarinda, said that the government of Samarinda was not constructing sidewalks. He said that there was no sidewalk construction for pedestrians due to budget limitation. The government of Samarinda provided regional budget to build and develop the road in Samarinda. The available budget could not be allocated to construct sidewalks.

\section{The Use of Sidewalks by Hawkers}

This study also found that the sidewalks had been misused by hawkers who sold their goods permanently or temporarily. Temporary hawkers came with their equipment and sold. After the place was empty or the goods had been sold out, they left the place immediately with their equipment. Whereas, permanent hawkers put a place to sell either in a deserted or crowded place, so the equipment was left in the place.

\section{The Use of Sidewalks as Parking Areas}

The increasing population was in line with the growing number of vehicles. Based on data from the Central Bureau of Statistics of East Kalimantan in the period 
of 2012 to 2015 , there was an increasing number of all types of vehicles ${ }^{24}$. However, its growth was not in line with the availability of parking areas in public spaces. Both two-wheeler and fourwheeler were parked by their owners not in its appropriate places, especially in crowded places like schools and traditional markets. Vehicles were also parked on sidewalks. As we know, sidewalks were intended for pedestrianonly which were protected by the regulations. Two-wheeler, four-wheeler, and above were prohibited for parking on public roads and sidewalks.

\section{The Supporting Factors}

\section{Law Certainty for the Society}

A legal certainty emphasized a person's rights and obligations. The right belonged to pedestrians was a place to walk, so they did not interfere with the others' rights such as walking on road bodies. The vehicle users also had a right to use roads for their safe driving. So the vehicle users obligated to drive carefully to protect both themselves and pedestrians.

\section{Law Orders for the Road Users}

24 "Data on the Number of Vehicles in 20122015" (Central Bureau of Statistics of East Kalimantan, 2016).

25 "Law of the Republic of Indonesia Number 35 of 2014 Regarding Amendment to Law
The lack of sidewalks in Samarinda caused chaos. The sidewalks in Samarinda were places for hawkers to sell and riders to park. Therefore, the government could provide sidewalks based on the regulations. Providing facilities could minimize the violations or crimes on the sidewalks. If the facilities were provided well, there was no reason for society not to walk. Then, it reduced the number of vehicles on roads for reducing the risk of road accidents.

\section{Legal Protection to Students}

Primary and high school students were categorized as children. According to Law Number 35 of 2014 concerning the protection of children in the age from 0 months to 18 years, the existence of the sidewalk was very important for the protection of the students ${ }^{25}$. The sidewalks had a function as a protection for students who used them. When a sidewalk changed its function as a selling place and a parking area, the protection was failed to be given.

\section{CONCLUSION}

Number 23 of 2002 Regarding Child Protection," 2014, https://www.bphn.go.id/data/documents/14uu03 5.pdf. 
70 | Suwardi Sagama, Legal Protections to Pedestrians..., hlm.56-70

The protection for pedestrians based on Article 131 of Law Number 22 of 2009 concerning Traffic and Road Transportation stated that pedestrians were entitled to the availability of supporting facilities such as sidewalks. The construction of sidewalks was an obligation for the government as regulated in Article 25 paragraph 1 letter 'g' of Law Number 22 of 2009 concerning Traffic and Road Transportation which mentioned every road used for the public must be equipped with pedestrian

\section{REFERENCES}

Ahmad, Siti Nurjanah, and Try Sugiyarto Soeparyanto. "Tinjauan Perilaku Pejalan Kaki dan Penyeberang Jalan pada Kawasan Fakultas Pertanian Universitas Haluoleo." Stabilita: Jurnal Ilmiah Teknik Sipil 1, no. 3 (2013): 275-290.

"Data of Markets in Samarinda." Office of Market Service of Samarinda, 2018.

"Data on Population in Samarinda from 2017 to 2018." Civil Registry Office of Samarinda, 2018.

"Data on the Number of Vehicles in 2012-2015." Central Bureau of Statistics of East Kalimantan, 2016.

Dwiyanto, Agung. "Kuantitas dan Kualitas Ruang Terbuka Hijau di Pemukiman Perkotaan." Jurnal Teknik 30, no. 2 (2009): 88-93.

"Educational Data of 2018/2019: Private and Public Islamic High Schools." Regional Office of Ministry of Religious Affairs of East Kalimantan, 2019. facilities. Even though it was an obligation for the government, sanctions were only given to the destroyers of pedestrian facilities and riders who did not prioritize pedestrian safety. The obstacles to the implementation of these laws were the limitation of budget, the use of sidewalks by hawkers, and the use of sidewalks as parking areas. Whereas the supporting factors for the implementation were legal certainty for the society, law orders for the road users, and legal protection to students.

"Educational Data of 2018/2019, Second

Semester: Private and Public Primary and Junior High Schools." Department of Education and Culture of Samarinda, 2019.

"Educational Data of 2018/2019, Second Semester: Private and Public Senior High Schools." Department of Education and Culture of East Kalimantan, 2019.

Hilman, Yusuf Adam. "Revitalisasi Konsep Alun-Alun sebagai Ruang Publik: Studi Pemanfaatan AlunAlun Ponorogo." Jurnal Aristo 3, no. 1 (2016): 28-37. https://doi.org/10.24269/ars.v3i 1.9.

Huda, Ni'matul. Ilmu Negara. Jakarta: Rajawali Press, 2010.

Kelsen, Hans. General Theory of Law and State. Translated by Anders Wedberg. New Jersey: The Lawbook Exchange, Ltd., 2007.

"Law of the Republic of Indonesia Number 22 of 2009 Concerning 
60 | Suwardi Sagama, Legal Protections to Pedestrians..., hlm.56-70

Road Traffic and Transportation," 2009.

"Law of The Republic of Indonesia Number 22 of 2009 Concerning Road Traffic and Transportation," 2009.

"Law of the Republic of Indonesia Number 28 of 1999 Regarding the Organization of a State That Is Clean and Free from Corruption, Collusion and Nepotism," 1999. https://www.kpk.go.id/gratifikas i/BP/uu_28_1999.pdf.

"Law of The Republic of Indonesia Number 34 of 2004 Regarding Road," 2004.

"Law of the Republic of Indonesia Number 35 of 2014 Regarding Amendment to Law Number 23 of 2002 Regarding Child Protection," 2014. https://www.bphn.go.id/data/d ocuments/14uu035.pdf.

Muchtar, Chaerul. "Identifikasi Tingkat Kenyamanan Pejalan Kaki : Studi Kasus Jalan Kedoya Raya Arjuna Selatan." Jurnal Planesa 1, no. 2 (2010): 153-59.

Prijadi, Rachmat, and Raymond D. Ch Tarore. "Pengaruh Permukaan Jalur Pedestrian Terhadap Kepuasan \& Kenyamanan Pejalan Kaki Di Pusat Kota Manado." Media Matrasain 11, no. 1 (2014): 43-54.

"Regulation of Minister of Public Works Number 19/ PRT / M / 2011 on Road Technical Requirements and Road Technical Planning Criteria," 2011.

"Regulation of the President of the Republic of Indonesia on Administration and Development of Traditional Market Shopping Centres and Modern Store," 2007. https://www.bphn.go.id/data/d ocuments/07pr112.pdf.

Satriyadi, Liliek, Bambang Haryadi, and Ismiyati -. "Prasarana Pedestrian
Di Lingkungan Kampus: Studi Kasus Kampus UNDIP Dan UNNES." Wahana Teknik Sipil: Jurnal Pengembangan Teknik Sipil22, no. 1 (2017): 58-70. https://doi.org/10.32497/wahan ats.v22i1.902.

Sianipar, Boy Leonardo. Interview with Boy Leonardo Sianipar on Punishment Activities Implemented by the Samarinda Transportation Office, July 2019.

Tribunnews.com. "Kasus Pengendara Sepeda Motor Serang Pejalan Kaki Berakhir Damai," September 10 , 2019.

https://www.tribunnews.com/m etropolitan/2019/09/10/kasuspengendara-sepeda-motorserang-pejalan-kaki-berakhirdamai.

Vicentius Hari Prabowo. Interview with V. Hari Prabowo on Punishment Activities Implemented by the Samarinda Transportation Office, July 2019.

Warsilan, Warsilan, and Akhmad Noor. "Peranan Infrastruktur Terhadap Pertumbuhan Ekonomi Dan Implikasi Pada Kebijakan Pembangunan Di Kota Samarinda." MIMBAR: Jurnal Sosial Dan Pembangunan 31, no. 2 (2015): 359-366. 